\title{
Territory of state as indivisible whole and the norms of Constitution
}

\author{
Professor Leonid TYMCHENKO ${ }^{1}$ \\ Associate professor Valerii KONONENKO ${ }^{2}$
}

\begin{abstract}
In the study of the substantive legal grounds for the resolution of territorial disputes, the judicial form is characterized by the priority of the grounds of legal title (agreemental title, uti possidetis) based on international treaties, or legal acts of the state possessing sovereignty over the grounds of actual title (effective occupation and governning of the territory, tacit recognition, prescriptional acquisition). Like the initial occupation, the acquisition of territory on the basis of prescription has a long and effective occupation of territory as a prerequisite. The possession of alien or contested territory without a treaty may be legal and enforceable only when there is an inviolable, uninterrupted and undisputed exercise of possession. Where the disputable territory is in fact administrated by a state other than that which holds title, the International Court of Justice gives preference to the title holder.
\end{abstract}

Keywords: territory, sovereignty, International Court of Justice, Constitution of the Czech Republic.

\section{JEL Classification: K33}

DOI: $10.24818 / \mathrm{TBJ} / 2021 / 11 / 3.05$

\section{Introduction}

The statement that territorial matters in international law are sufficiently researched, which leads to a relatively low interest in the issue ${ }^{3}$, can hardly be accepted. The evidence of the contrary have been the recent events in Ukraine as well as territorial disputes in Europe: between Great Britain and Spain (Gibraltar), Canada and Denmark (Hans Island), Greece and Turkey, Croatia and Slovenia (the passage of the maritime border in the Gulf of Piran, resolved by the International Arbitration), the Czech Republic and Poland (when after the division of state borders in 1958 there was 368 hectares more on the Czech side) and many others.

Delimitation of territorial sovereignty is one of the most pressing issues of the contemporary international law. Thus, despite the evolving political movements

\footnotetext{
${ }^{1}$ Leonid Tymchenko - Doctor of Law, Professor, Chief Research Fellow, Department of International Tax Competition, Research Institute of Fiscal Policy, University of the State Fiscal Service of Ukraine, Irpin, Ukraine, ltymch@ukr.net.

${ }^{2}$ Vaierii Kononenko - Doctor of Law, Associate Professor, Department of International Economic Relations and Tourist Business, V. N. Karazin Kharkiv National University, Kharkiv, Ukraine, v.kononenko@karazin.ua.

${ }^{3}$ Kivalova, T., Korotkiy, T. Development of international law research in Ukraine in 1991-2012.In: International law as the basis of the modern world order: collective monograph Liber Amicorum for the 75th anniversary of Prof. V.N. Denisov (Kiev-Odessa: Phenix, 2012) 222.
} 
for the creation of states without borders ${ }^{4}$, globalization has not led to a world in which borders do not matter ${ }^{5}$. At the same time, as A.A. Merezhko stresses, the globalization processes have had a devastating impact on the traditional system of sovereign states and the international law corresponding to it $^{6}$. Therefore, steps towards the elimination of the existing differences and disputes among states have been of a significant contribution to strengthening the international peace and security ${ }^{7}$.

The role of the territory is of critical importance in terms of the contemporary theory of state and its functions. Correspondingly, its protection implies the indivisibility of territory, its unitarity within state borders ${ }^{8}$. Ensuring territorial integrity and unity is the primary function of any state 9 .

Territory in the doctrine and practice of international law refers to various spaces of the globe, including its land and water surfaces, subsoil, airspace, as well as outer space and celestial bodies. The problematic of the territorial supremacy, sovereign rights over a space, the scope of activities in that space or the use of its resources is directly related to the political and economic relations and, ultimately, to the material conditions of states and peoples ${ }^{10}$.

\section{State sovereignty}

Sovereignty emphasizes the legal nature of the state territory. Under the international law, a territory is linked to its population. State territory and its population are necessary prerequisites of any $\operatorname{state}^{11}$. The notion of the territorial supremacy, like that of the state sovereignty, is not absolute. Trends in the contemporary international law demonstrate that a state is free to exercise its territorial supremacy to the extent that the rights and legitimate interests of other states are not affected. There is a clear reason for that: as the international community is made up of independent states, the sovereignty of one is necessarily

\footnotetext{
${ }^{4}$ Fabri, H. `Immateriel, territorialite et Etat’, Arch. phil. droit, vol. 43 (1999) 187.

${ }^{5}$ Kumm, M. 'The legitimacy of international law: a constitutionalist framework of analysis', The European Journal of International Law. vol. 15, no. 5 (2004) 913.

${ }^{6}$ Olecsandr Merezhko. 'The crisis of modern microsystem and the future of international law in the 21 st century`. Almanac of International Law, no. 2 (2010) 22.

${ }^{7}$ Ali Bin Abadi, G. Peaceful settlement of Yemen's territorial disputes with neighbouring states: International legal aspects. Ph. D. Thesis (Moscow, 2000) <https://www.dissercat.com/ content/mirnoe-uregulirovanie-territorialnykh-sporov-iemena-s-sosednimi-gosudarstvamimezhdunarodno-> accessed 10 June 2021.

${ }^{8}$ Zhaliy, T. 'International principles of territorial integrity and inviolability of borders of state in the context of the necessity of their study in the law courses of universities of Ukraine'. Almanac of International Law, no. 10 (2015) 15.

${ }^{9}$ See: Salimov, R. Problems of implementing the principle of territorial integrity and inviolability of borders of states at the present stage. Referat of Ph. D. Thesis (Baku, 2010) 11.

${ }^{10}$ Leonid Timchenko, Valeriy Kononenko. International law, textbook (Kiev: Knowledge, 2012), 352-353.

${ }^{11}$ Leonid Timchenko. International law, text-book, $3^{\text {rd }}$ edition (Kharkov: Konsum, 2004) 285.
} 
limited by the sovereignty of the others ${ }^{12}$. Thus, it is crucial to ensure an equilibrium between the interests of all the parties, taking into account the norms of national and international law, previous universal and bilateral agreements (if any), as well as the practice of international courts.

Let us focus now on the situation between the Czech Republic and Poland (when after the division of state borders in 1958 there was 368 hectares more on the Czech side). On March 5, 1947, during the discussion of the German issue at the London Conference of Deputy Foreign Ministers and on the eve of the Moscow session of Foreign Ministers, a communiqué on reaching an agreement was issued in Poland and Czechoslovakia. On March 10, 1947 the Treaty of Friendship and Mutual Aid between the Republic of Poland and the Czechoslovak Republic was signed. By a special protocol, it was deemed necessary, through further negotiations, to resolve all contentious issues, including the Polish-Czechoslovak border, which was implemented in $1958^{13}$. Border adjustment of 1976 did not eliminate the problem and Poland demanded the repayment of its territorial debt. On its side, the Czech Republic offered Poland several territories in the border area. But the situation is still far from being resolved. For example, in 1992 the parties signed the Agreement on the invariability of borders. According to Article 11 of the Czech Constitution, the territory of the Czech Republic forms an indivisible whole, the borders of which may be altered only by a constitutional act $^{14}$.

Thus, neither the Czech constitutional norms nor the provisions of the treaty between the parties reflect the interests of Poland and do not contribute to a quick solution of the problem.

Moreover, a unilateral territorial claim does not constitute a territorial dispute. Characterizing the foundations of an interstate dispute, the United Nations International Court of Justice, in its Judgment on Preliminary Objections in the case concerning South-West Africa of December 21, 1962, stated that, in a contentious case, it was not enough for one party to claim a dispute with the other. It must be shown that the claims of one party are manifestly opposed to those of the other party ${ }^{15}$. In a unilateral territorial claim, the claimant state does not contest the very existence of the legal affiliation of a certain territory to a particular state, but considers, for some reason, that it has lost its right to it. British international lawyer R. Jennings highlights the difference between questions about who is entitled to a territory and whether that right should be changed for one reason or another ${ }^{16}$. The

${ }^{12}$ Kokoroko, D. 'Souveraineté étatique et principe de légitimité démocratique`, Revue quebecoise de droit international, vol. 16.1 (2003) 39.

${ }^{13}$ Noskova, A., Pop, I. 'Establishment of the system of agreemental relations between the USSR and the countries of people's democracy (1945-1949)'. Soviet Slavonic Studies, no. 4 (1983) 9.

14 The Constitution of the Czech Republic (1993) <http://www.psp.cz/en/docs/laws/constitution. html $>$ accessed 10 June 2021

15 South West Africa Cases (Ethiopia v. Soztth Africa; Liberia v. South Africa), Preliminnry Objections, Judgment of 21 December 1962, I.C. J. Reports (1962) 319.

16 Jennings, R. Acquisition of territory in international law (Manchester: Manchester University Press, 1963) 14. 
distinction between territorial disputes and unilateral claims is also made by American scientist A. Burhart, noting that the latter have no strict legal grounds ${ }^{17}$.

An example of a unilateral territorial claim is Iraq's claim to sovereignty over Kuwait (1961-1963). In 1945, Kuwait began to develop oil fields and in 1961 it declared its independence, which was followed almost immediately by a declaration by the then government of Iraq of its right to exercise sovereignty over Kuwait on the basis that the latter was once part of Iraq. After difficult and significant events (presence of foreign troops in Kuwait, Kuwait's joining the League of Arab States and the UN), Iraq in 1963 recognized Kuwait's independence and renounced its territorial claim. At the same time, in 1963, a protocol was signed in Baghdad, which in turn confirmed the border established in 1932 through the exchange of messages between the Prime Minister of Iraq and the ruler of Kuwait. After the finishing of the Operation Desert Storm (January 17, 1991 - February 28, 1991) the International Commission for the Demarcation of the Iraq-Kuwait Boundary was established in May 1991 by the United Nations Security Council in its resolution 687. It comprised of one representative from Iraq and one from Kuwait as well as of three independent experts appointed by the United Nations Secretary-General. Formally, the Commission did not deal with the territorial redefinition but rather with a technical work on delimitation and demarcation. By defining geographical coordinates and establishing boundary pillars and markers, in parallel the Commission carried out a new survey and mapping of the entire length of the boundary zone. In April 1992, the majority of the Commission called for the boundary passing through the disputed Rumaila oil field to be pushed back by 570 yards to Iraq. Part of the city of Umm Qasr was also placed under Kuwaiti control. Since then, Iraq has not participated in the work of the Commission at all. In July 1992, after completing the demarcation of the boundary between Batin and Samfan, the Commission declared that the oil fields located between the two locations were within Kuwaiti territory. In March 1993 , the Commission decided to demarcate the shallow water boundary in the Khor Al Zubair area. It established geographical coordinates to determine the median line from the point closest to the crossing of the Khor Al Zubair and Khor Abdullah waterways to the point at the eastern end of the Khor Abdullah where the general direction of the coastline changes. Formally, the Commission was guided by the fact that the accessibility for navigation of the various parts of the territories of the two states adjacent to the demarcated border should be an important precondition for ensuring equality and strengthening stability, peace and security in the border area. The right to ensure the possibility of navigation derives, in the opinion of the Commission, from international law, primarily from the 1982 United Nations Convention on the Law of the Sea, ratified by the parties to the dispute.

On May 27, 1993, the United Nations Security Council endorsed the decisions of the Final Boundary Demarcation Commission and demanded that Iraq and Kuwait respect the inviolability of the border by affirming their intention to

${ }^{17}$ Andrew Burghardt. `The bases of territorial claims `, Geographical Review, no. 2 (1973) 228. 
guarantee this inviolability by all means. In addition to territorial losses, Iraq faced the fact that its citizens on the Kuwaiti side of the border were not permitted to remain in Kuwait. However, Iraq stated that it would not take any action that could be construed as an acknowledgement of injustice deliberately imposed on it ${ }^{18}$.

As A.S. Orlov stresses, when it comes to the settlement of a territorial dispute, the mechanism for solving a territorial dispute consists of a set of actions of its participants, corresponding to a certain legal procedure and is aimed at settling territorial disputes (a form of dispute settlement in the broad sense). Agreemental and judicial forms have specific features of the resolution procedure. In the narrow sense, the form for the settlement of a territorial dispute is understood as an act concluding the dispute itself. The outcome of the settlement of territorial disputes is an agreement of the parties or decisions of jurisdictional bodies - courts and tribunals. Each of the forms of settlement of territorial disputes has features of the procedural nature, which are due to the specifics of the process of proving the substantive legal grounds for the resolution of the dispute ${ }^{19}$.

The judicial form is characterized by the procedural possibility of a consistent compliance with the basics of the procedure of proving: competitiveness and equality of the parties, following the subject of proving, application of the concept of "critical date" and estoppel, verification of evidence as to its relevance, admissibility, credibility and sufficiency. In the question of the substantive legal grounds for the judicial settlement of territorial disputes, there is a priority of the grounds of legal title (agreemental title, uti possidetis), based on international treaties or legal acts of the state possessing sovereignty, over the grounds of actual title (effective occupation and administration of the territory, tacit recognition, prescriptional acquisition). In doing so, the courts take into consideration the special circumstances of the dispute. The treaty form of resolving territorial disputes has not developed a clear criterion that determines the priority of certain grounds, and the factor of special circumstances has a much greater influence in it compared to the judicial form. The process of settling territorial disputes is affected by a variety of factors of both legal and non-legal nature - political and economic ${ }^{20}$.

\section{Practice of the International Court of Justice concerning territorial disputes}

Analyzing the case law of the UN Court, we consider it important to assess the territorial issue between the Czech Republic and Poland, taking into account

\footnotetext{
${ }^{18}$ See: Baburin, S. Territory of state: theoretical and legal problems. Referat of LL. D. Thesis (Moscow, 2005) <http://www.disser cat.com/content/territoriya-gosudarstva-teoretiko-pravovyeproblemy $>$ accessed 10 June 2021.

19 Orlov, A. International territorial disputes: correlation between treaty and judicial forms of settlement. Referat of Ph. D. Thesis (Yekaterinburg, 2009) 6.

${ }^{20}$ Ibid.
} 
the Court's practice. Although the Court itself argued that it does not create law, as M. Shaw notes, its numerous positions on what is law have the highest authority ${ }^{21}$.

One of the first territorial cases brought before the International Court of Justice concerned a dispute between Belgium and the Netherlands in respect of sovereignty over Certain Frontier Land ${ }^{22}$. It was submitted to the International Court of Justice under the special agreement concluded between the two governments on March 7, 1957, because they had been unable to agree on sovereignty of the two disputed 14-hectare cadastral boundary areas for several years. In particular, the area north of the Belgian town of Turnhout has a number of enclaves formed by the Belgian commune Baerle-Duc and the Dutch commune Baarle-Nassau.

The territory of the former consists of a number of plots, many of which are surrounded by the lands of the Baarle-Nassau commune. Different parts of the Baerle-Duc commune are not only isolated from the main Belgian territory, but also from each other. As a result of attempts to define the border between the two communes, as well as between the two countries, a document known as "Communal Minute" was drawn up between 1836 and 1841 by the authorities of both communes, in the section entitled "Section A called Zondereygen" which says: «Plots numbers 78 to 111 inclusive belong to the commune of BaarleNassau» ${ }^{23}$.

The Communal Minute, describing the border of 1843, says: "The plots with numbers 78-90 inclusive belong to the Baarle-Nassau municipality. Plots under numbers 91 and 92 belong to the municipality of Baerle-Duc. Plots 93-111 inclusive belong to Baarle-Nassau"24. In addition, a special map attached to the Boundary Convention shows the disputed plots as belonging to Belgium.

The Government of the Netherlands argued that the Boundary Convention of 1843 merely recognized the existence of a status quo without defining it. This status quo must be determined in accordance with the Communal Minute, according to which sovereignty over the disputed areas was recognized to be that of the Netherlands and the provision concerning the disputed areas in the Boundary Convention of 1843 was misrepresented. Moreover, the sovereign actions it took in practice in respect of these sites since 1843 invalidate the rights arising from the Boundary Convention of 1843 and confer sovereignty to the Netherlands.

The assertion concerned the exercise of sovereign actions in respect of these areas since 1843 secured sovereignty of the Netherlands. The Court should therefore answer the question whether Belgium had lost its title by failing to affirm

${ }^{21}$ Shaw, M. International law (Cambridge: Cambridge University Press, 1997) 749.

${ }^{22}$ Case concerning sovereignty over Certain Frontier Land of 20 June 1959, I. C. J. Reports (1959) 209 or Website of the International Court Justice (1959) <https://www.icj-cij.org/en/case/38> accessed 10 June 2021.

${ }^{23}$ Case concerning sovereignty over Certain Frontier Land of 20 June 1959, I. C. J. Reports (1959) 209 or Website of the International Court Justice (1959) <https://www.icj-cij.org/files/caserelated/38/038-19590620-JUD-01-00-EN.pdf> accessed 10 June 2021.

${ }^{24}$ Ibid. 
its rights and by acquiescing in the sovereign acts which had allegedly been repeatedly exercised by the Netherlands after 1843.

The UN Court found that the actions pointed out by the Netherlands were primarily of an ongoing administrative nature, resulting from the inclusion of the disputed areas by the Netherlands in its surveys, contrary to the Boundary Convention of 1843. They do not provide sufficient grounds to consider that the Belgian sovereignty established by the Convention is no longer in force.

As we can see, the Netherlands based its position on the rationale for acquiring sovereignty over the disputed area on the institution of effective occupation and acquisitive prescription. Like the initial occupation, the acquisition of territory on the basis of a priori possession also has as a precondition a prolonged and effective occupation of territory. However, this type of acquisition differs from the initial occupation in that it relates to a territory that was, at the time when the other state was still occupying the state territory or if there was a dispute between the two states over whether the territory belonged to one of them.

Such occupations do not justify the immediate acquisition of territory, since the effective dominance can be only then and only to the extent of the definite rights, since it is the legal effect that international law associates with it. The possession of a territory that is alien or disputed without a treaty is legal and law establishing only when there is an unbroken, uninterrupted and undisputed exercise of domination, as was noted in the American-Mexican arbitral decision in the case of El Chamizal of June 15, $1911^{25}$.

The Court also recognized that the Boundary Convention of 1843 in fact determines which parts of each commune belong to a particular state, and that under its provisions the disputed territories belong to Belgium.

With regard to the second allegation, that mistake took place in the Boundary Convention of 1843 , the UN Court noted that a comparison of the Communal Minute copy submitted by the Netherlands with a protocol describing the boundary shows that the former was not reproduced verbatim, since the boundary protocol lists sections 91 and 92 as Belgian possessions, whereas according to this copy of the Communal Minute they are considered to belong to Baarle-Nassau. The UN Court found that a simple comparison of these two documents does not give reason to say that there is an error. In order to establish this, the Netherlands had to prove that the Mixed Boundary Commission intended to include in the Boundary Convention of 1843 , as an integral part, the protocol describing the boundary, i. e. the text of the Communal Minute contained in the copy submitted by the Netherlands. The UN Court thus pointed out that each party had a duty to prove the circumstances to which it referred as the basis of its claims and objections and determined the subject matter of the first question of proof - the intention of the Mixed Boundary Commission to carry out the specific actions referred to above.

${ }^{25}$ See: Verdross, A. International law (Moscow: International Literature, 1959) 258. 
Given the long time that had passed since the Commission's work, the Netherlands was not able to complete such a difficult task. The difficulty was that it was not the actual fact that had to be proven, but the Commission's intention. It should be pointed out here that, in accordance with the practice of the UN Court of Justice, the failure of a party to a dispute to confirm a certain argument does not automatically mean that the opposing party is right. Thus, in the case concerning the border dispute between Burkina Fuso and Republic of Mali of December 22, 1986, the Chamber of the International Court of Justice pointed out that the systematic application of the rule on the burden of proof could not always ensure a proper decision, and the rejection of any particular argument on account of its unprovenability could not be a sufficient reason to support the opposing argument ${ }^{26}$.

Thus, the effective implementation of the territorial supremacy over an extended period of time, under certain conditions, may be essential for determining sovereignty of a disputed area, unless there is an international agreement to that effect. But, if there is an international treaty to that effect, concluded in accordance with generally recognized principles and rules of international law, in the event of a dispute the specific agreement between the parties would be crucial in determining the scope of the territorial supremacy. And if there is a combination of both treaty title and the effective exercise of the territorial supremacy, in the case of claims by the other party, it is not difficult to predict the outcome of the proceedings: it is beyond reasonable doubt that the state designated as such in the treaty will be recognized as sovereign ${ }^{27}$.

The decision on the Case concerning sovereignty over Certain Frontier Land of June 20, 1959, draws attention to the importance of an error in international agreements and the need to prove its existence. From the legal point of view, the question of an error may be important in that it suggests the relative invalidity of an international treaty, which means that it is rebuttable. Most often, the relative invalidity of a treaty is due to an error, deception, bribery of a state representative, breach of authority or constitutional provisions in its conclusion. The right to challenge arises for a state if the violation of certain provisions of domestic law governing the procedure for concluding international treaties was significant and evident ${ }^{28}$. A significant error, i.e. a misstatement of the true will of the parties or of at least one party, an error contained in the text of the treaty itself may give rise to doubts as to the legal validity of the signed act in part or even as a whole. However, the claim that such an error exists must be proved convincingly ${ }^{29}$, since international law has a presumption of the validity of treaties (art. 42 of the 1969 Vienna Convention on the Law of Treaties).

${ }^{26}$ Frontier Dispute (Burkina Fuso/Republic of Mali), Judgment, I. C. J. Reports (1986) 37, para 65.

27 Frontier Dispute (Burkina Fuso/Republic of Mali), Judgment, I. C. J. Reports (1986) 587, para 63.

28 See: Leonid Timchenko. International law, text-book, $3^{\text {rd }}$ edition (Kharkov: Konsum, 2004) 100.

29 See: Kozhevnikov, F. International Court of Justice. Organization, aims, practice (Moscow: International Relations, 1971) 86. 
Interestingly, Belgium and the Netherlands have experience not only in the judicial settlement of territorial disputes, but also in exchanging parts of the territory by a treaty. What is important for the topic of this article is not equal parts of the territory. On January 1, 2018, the interstate agreement came into force, which changed the border line between Belgium and the Netherlands. This exchange was a unique case in post-war Europe, where two states peacefully agreed to change the border, with the Netherlands receiving more territory from Belgium than it gave it. Belgium received a peninsula of 3 hectares and the Netherlands 16 hectares. The basis for the border adjustment was the change in the course of the Meuse River between the city of Eisden in the Netherlands and the Belgian municipality of Vese. As a result of engineering work on the river in the 1960s-80s, the former Belgian island became a peninsula connected with the Netherlands and vice versa, the Dutch island physically joined Belgium. This situation made it very difficult for law enforcement agencies to act. The key problems were related to the former Belgian island, which was quite large in size. In the case of a reported crime, the Dutch law enforcement agencies could not go in there. The Belgian police could only get there by boat, as they were not allowed to transit through the Dutch territory. The peninsula had therefore become a site for drug trafficking crimes.

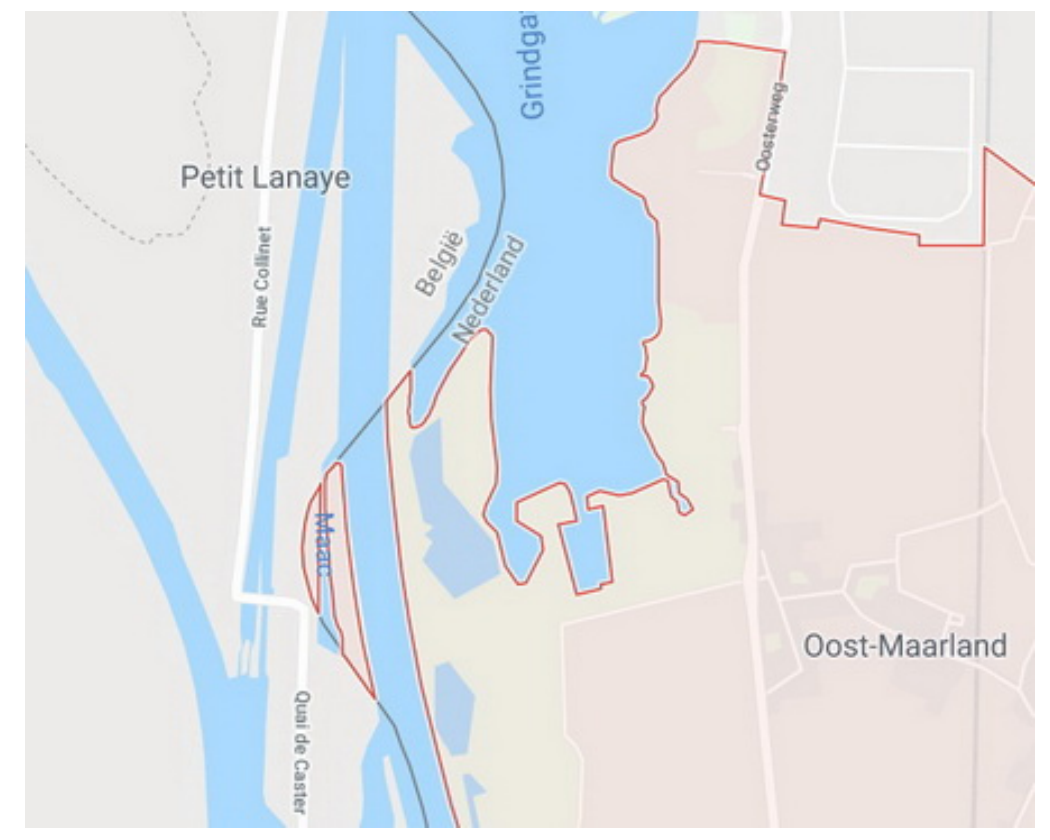

The old border between Belgium and the Netherlands ${ }^{30}$.

30 Belgium and the Netherlands changed the state border and exchanged territories (2018) $<$ https://www.eurointegration.com.ua/rus/ news/2018/01/1/7075649/> accessed 10 June 2021. 


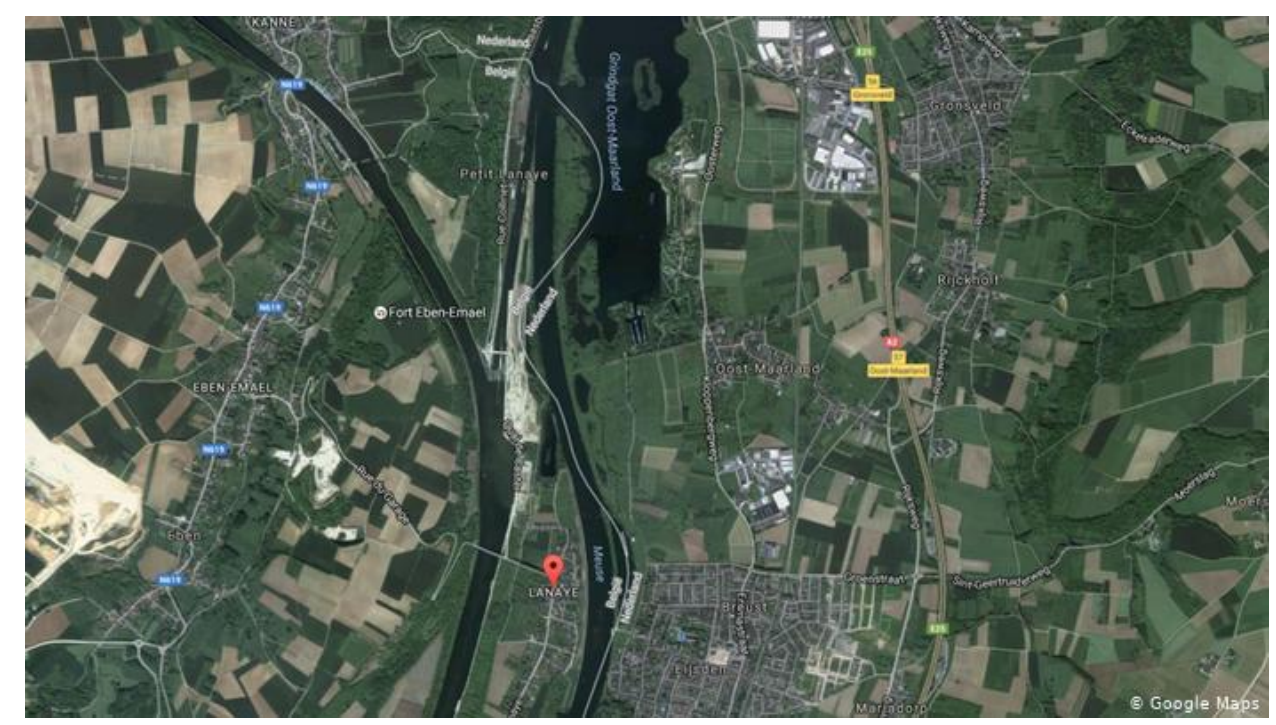

A Google Maps screenshot shows the twisting and turning old border that created pockets of Belgian and Dutch territory on opposite sides of the Meuse River ${ }^{31}$.

Thus, European countries have the practice of solving territorial problems both through judicial and treaty procedures. We believe that for Poland and the Czech Republic the only acceptable way out of the above described situation is to conclude a relevant treaty. The judicial procedure in this case will not provide the Polish side with a positive result. Firstly, as stated earlier, a unilateral claim is not considered a territorial dispute by the UN Court. And secondly, in the question of the substantive legal grounds for resolving territorial disputes, the UN Court recognizes the priority of legal title (agreemental title, uti possidetis) over actual title (effective possession and governing of the territory, tacit recognition, prescriptional acquisition).

Moreover, in the Case concerning the land and maritime boundary between Cameroon and Nigeria (Cameroon v. Nigeria) of October 10, 2002, the International Court of Justice noted that if the territory in dispute is in fact administered by a different state from that which holds title, preference should be given to the holder of the title ${ }^{32}$.

\section{Conclusions}

With regard to the main problem discussed in the article, it can be said that the disputed part of the territory is owned by the Czech Republic on the basis of

${ }^{31}$ Belgium and Netherlands swap land in the New Year $(2018)<$ https://www.dw.com/en/belgiumand-netherlands-swap-land-in-the-new-year/a-41988494> accessed 10 June 2021.

${ }^{32}$ Land and maritime boundury hetween Cameroon and Nigeria (Cameroon $v$. Nigeria: Equatorial Guineu intervening), Judgment, I.C.J. Reports (2002): 355, para 70. 
legal title (the 1958 Treaty), the acquisition limitation confirmed (the 1976 Act and the 1992 Treaty) and the effective occupation can be considered as optional grounds. In other words, in a case of trial, the decision would definitely be in favour of the Czech Republic. All this does not prevent the Czech Republic from unilaterally adopting the relevant constitutional act on border change. And the only acceptable option for Poland and the Czech Republic is the conclusion of a relevant treaty.

\section{Bibliography}

1. Ali Bin Abadi, G. Peaceful settlement of Yemen's territorial disputes with neighbouring states: International legal aspects. Ph. D. Thesis (Moscow, 2000) $<\mathrm{https}$ ://www.dissercat.com/content/mirnoe-uregulirovanie-terri torialnykh-sporoviemena-s-sosednimi-gosudarstvami-mezhdunarodno-> accessed 10 June 2021.

2. Andrew Burghardt. 'The Bases of Territorial Claims', Geographical Review no. 2 (1973): 225-245.

3. Baburin, S. Territory of state: theoretical and legal problems. Referat of LL. D. Thesis (Moscow, 2005) http://www.dissercat.com/content/territoriya-gosudarstvateoretiko-pravovye-problemy accessed 10 June 2021.

4. Belgium and the Netherlands changed the state border and exchanged territories (2018) <https://www.euro integration.com.ua/rus/news/2018/01/1/7075649/> accessed 10 June 2021.

5. Belgium and Netherlands swap land in the New Year (2018) $<$ https://www.dw.com/en/belgium-and-nether lands-swap-land-in-the-new-year/a41988494> accessed 10 June 2021.

6. Case concerning sovereignty over Certain Frontier Land of 20 June 1959, I. C. J. Reports (1959): 209 or Website of the International Court Justice (1959) $<$ https://www.icj-cij.org/en/case/38> accessed 10 June 2021.

7. Case concerning sovereignty over Certain Frontier Land of 20 June 1959, I. C. J. Reports (1959): 209 or Website of the International Court Justice. (1959) $<$ https://www.icj-cij.org/files/case-related/38/038-19590620-JUD-01-00-EN.pdf> accessed 10 June 2021.

8. Fabri, H. 'Immateriel, territorialite et Etat', Arch. phil. droit vol. 43 (1999): 187-212.

9. Frontier Dispute (Burkina Fuso/Republic of Mali), Judgment, I. C. J. Reports (1986).

10. Kivalova, T., Korotkiy, T. Development of international law research in Ukraine in 1991-2012. In: International law as the basis of the modern world order: collective monograph Liber Amicorum for the 75th anniversary of Prof. V.N. Denisov (KievOdessa: Phenix, 2012).

11. Kokoroko, D. 'Souveraineté étatique et principe de légitimité démocratique`. Revue quebecoise de droit international vol. 16.1 (2003): 37-59.

12. Kozhevnikov, F. International Court of Justice. Organization, aims, practice (Moscow: International Relations, 1971).

13. Kumm, M. 'The Legitimacy of International Law: A Constitutionalist Framework of Analysis', The European Journal of International Law vol. 15, no. 5 (2004): 907-931.

14. Land and maritime boundary between Cameroon and Nigeria (Cameroon v. Nigeria: Equatorial Guineu intervening), Judgment, I. C. J. Reports (2002).

15. Leonid Timchenko, Valeriy Kononenko. International law, textbook (Kiev: Knowledge, 2012). 
16. Leonid Timchenko. International law, text-book, $3^{\text {rd }}$ edition (Kharkov: Konsum, 2004).

17. Noskova, A., Pop, I. 'Establishment of the system of agreemental relations between the USSR and the countries of people's democracy (1945-1949)', Soviet Slavonic Studies no. 4 (1983): 3-18.

18. Olecsandr Merezhko. 'The crisis of modern microsystem and the future of international law in the 21st century', Almanac of International Law no. 2 (2010): $12-24$.

19. Orlov, A. International territorial disputes: correlation between treaty and judicial forms of settlement. Referat of Ph. D. Thesis (Yekaterinburg, 2009).

20. Salimov, R. Problems of implementing the principle of territorial integrity and inviolability of borders of states at the present stage. Referat of $\mathrm{Ph}$. D. Thesis (Baku, 2010).

21. Shaw, M. International law (Cambridge: Cambridge University Press 1997).

22. Jennings, R. Acquisition of territory in International Law (Manchester: Manchester University Press, 1963).

23. South West Africa Cases (Ethiopia $v$. Soztth Africa; Liberia v. South Africa), Preliminnry Objections, Judgment of 21 December 1962, I.C.J. Reports (1962).

24. The Constitution of the Czech Republic (1993) <http://www.psp.cz/en/docs/laws/ constitution.html $>$ accessed 10 June 2021.

25. Verdross, A. International law (Moscow: International Literature, 1959).

26. Zhaliy, T. 'International principles of territorial integrity and inviolability of borders of state in the context of the necessity of their study in the law courses of universities of Ukraine', Almanac of International Law no. 10 (2015): 12-19. 